\title{
Mechanistic Effects of Vitamin D Supplementation on Metabolic Syndrome Components in Patients with or without Vitamin D Deficiency
}

\author{
Samira Faraji ${ }^{1,2}$, Mohammad Alizadeh ${ }^{2,3, *}$ \\ 'Student Research Committee, ${ }^{2}$ Department of Nutrition, School of Medicine, and ${ }^{3}$ Food and Beverages Safety Research Center, Urmia University of Medical \\ Sciences, Urmia, Iran
}

The prevalences of metabolic syndrome (MetS) and vitamin D deficiency are increasing dramatically worldwide. MetS is a major challenge because it can increase the risk of most non-communicable diseases. The beneficial effect of vitamin D on MetS components remains controversial, so the present review focused on the clinical effects of vitamin D supplementation on MetS components. Vitamin D can inhibit the protein expression of nuclear factor beta; improve arterial stiffness; decrease renin-angiotensin-aldosterone system activity, parathyroid hormone levels, inflammatory cytokines, 3-hydroxy-3-methylglutaryl-coenzyme A reductase, and lanosterol 14 $\alpha$-demethylase enzyme activity; increase the activity of lipoprotein lipase; alter gene expression in $\mathrm{C} 2 \mathrm{C} 12$ cells; and improve phospholipid metabolism and mitochondrial oxidation. We tried to elucidate and analyze almost all evidence from randomized controlled trial studies of the efficacy of vitamin D supplementation in patients with MetS. The findings of the present study reported beneficial effects of vitamin D supplementation on mentioned factors. Vitamin D supplementation is recommended in people with vitamin D deficiency even if it has no considerable effect on most MetS factors. However, existing data from interventional studies are insufficient to reach a definitive conclusion about the effect of vitamin D supplementation on MetS components in patients without vitamin D deficiency. Thus, new clinical studies are needed to test the hypothesis that vitamin D supplementation could alleviate MetS components in patients with sufficient intake of vitamin D.
Received December 30, 2019

Reviewed January 21, 2020

Accepted May 17, 2020

*Corresponding author

Mohammad Alizadeh

(iD)

https://orcid.org/0000-0002-0593-1491

Department of Nutrition, School of Medicine and Food and Beverages Safety Research Center, Urmia University of Medical Sciences, Urmia 5756115111, Iran

Tel:+98-44-3275-2372

Fax:+98-44-3278-0800

E-mail: alizadeh.m@umsu.ac.ir

Key words: Metabolic syndrome, Vitamin D, Obesity, Hypertension

\section{INTRODUCTION}

Metabolic syndrome (MetS), also known as syndrome X, visceral adiposity syndrome, or insulin resistance syndrome, includes hyperlipidemia, hypertension, hyperglycemia, insulin resistance, abdominal obesity, and proinflammatory states. ${ }^{1-3} \mathrm{MetS}$ is a major challenge worldwide because it can increase the risk of other diseases, such as a two-fold increase in risk for cardiovascular disease, two- to four-fold for stroke, fivefold or more for type 2 diabetes, and three- to four-fold for myocardial infarction., ${ }^{4,5}$ According to Table 1, there are several definitions for MetS.,6,7
The prevalence of MetS is increasing dramatically across the world. ${ }^{8}$ According to the International Diabetes Federation (IDF), overall global prevalence of MetS was at about $25 \%$ in $2006 .{ }^{9}$ In 2007, up to $34.7 \%$ of the adult population in the Middle East had MetS, based on criteria from the National Cholesterol Education Program-Adult Treatment Panel III. ${ }^{10}$ In addition, 37.4\% of adult population in the Middle East had MetS in 2007 based on the IDF definition. ${ }^{10}$ The prevalence of MetS increases with age, and the mortality of persons with MetS is higher than that of people without it.,11

Positive family history, cigarette smoking, higher age, obesity, low socioeconomic status, vitamin D deficiency, consumption of fast

Copyright (C) 2020 Korean Society for the Study of Obesity

(a) This is an Open Access article distributed under the terms of the Creative Commons Attribution Non-Commercial License (https://creativecommons.org/licenses/by-nc/4.o/) which permits unrestricted non-commercial use, distribution, and reproduction in any medium, provided the original work is properly cited. 
Table 1. Definition of Met $S^{3,6,7}$

\begin{tabular}{|c|c|}
\hline World Health Organization & $\begin{array}{l}\text { Insulin resistance or glucose level }<6.1 \mathrm{mmol} / \mathrm{L}, 2 \text {-hour } \mathrm{OGT}<7.8 \mathrm{mmol} / \mathrm{L} \text { together with } 2 \text { or more of the following factors: } \\
\mathrm{HDL}-\mathrm{C}<35 \mathrm{mg} / \mathrm{dL} \text { in males, }<40 \mathrm{mg} / \mathrm{dL} \text { in females } \\
\text { Triglycerides }>150 \mathrm{mg} / \mathrm{dL} \\
\text { Waist-to-hip ratio }>0.9 \text { (males) or }>0.85 \text { (females) or BMl }>30 \mathrm{~kg} / \mathrm{m}^{2} \\
\text { Blood pressure }>140 / 90 \mathrm{mmHg}\end{array}$ \\
\hline $\begin{array}{l}\text { National Cholesterol Education Program-Adult } \\
\text { Treatment Panel III }\end{array}$ & $\begin{array}{l}\text { Three or more of the following factors: } \\
\text { Blood glucose }>100 \mathrm{mg} / \mathrm{dL} \text { or taking medication for medical care of it } \\
\mathrm{HDL}-\mathrm{C}<40 \mathrm{mg} / \mathrm{dL} \text { in males, }<50 \mathrm{mg} / \mathrm{dL} \text { in females or taking medication to regulate } \mathrm{HDL}-\mathrm{C} \text { levels } \\
\text { Blood triglycerides }>150 \mathrm{mg} / \mathrm{dL} \text { or taking medication to regulate triglyceride levels } \\
\text { Waist circumference }>102 \mathrm{~cm} \text { for males or }>88 \mathrm{~cm} \text { for females } \\
\text { Blood pressure }>130 / 85 \mathrm{mmHg} \text { or taking medication for hypertension }\end{array}$ \\
\hline International Diabetes Federation & $\begin{array}{l}\text { Waist circumference }>94 \mathrm{~cm} \text { for males or }>80 \mathrm{~cm} \text { for females together with } 2 \text { or more of the following factors: } \\
\text { Blood glucose }>100 \mathrm{mg} / \mathrm{dL} \text { or diabetes } \\
\text { Blood triglycerides }>150 \mathrm{mg} / \mathrm{dL} \text { or taking medication to regulate triglyceride levels } \\
\text { SBP }>130 \mathrm{mmHg} \text { and DBP }>85 \mathrm{mmHg} \text { or taking medication for hypertension }\end{array}$ \\
\hline
\end{tabular}

MetS, metabolic syndrome; OGT, oral glucose tolerance test; HDL-C, high-density lipoprotein cholesterol; BMI, body mass index; SBP, systolic blood pressure; DBP, diastolic blood pressure.

food, Mexican-American ethnicity, postmenopausal status, physical inactivity, stress, drinking sweetened beverages, alcohol consumption, Western diet, increasing urbanization, genetic predisposition, low cardiorespiratory fitness, low birth weight, and too much television watching are important risk factors for MetS. ${ }^{12-14}$

Vitamin D has been called the "sunshine vitamin". ${ }^{15}$ The most important constituents of this vitamin in humans, vitamin D3 (cholecalciferol) and vitamin D2 (ergocalciferol), are converted to 25hydroxyvitamin $\mathrm{D}$ in the liver, which is the most important form of vitamin $\mathrm{D}$ for determining the level of vitamin $\mathrm{D}$ in the bloodstream. ${ }^{16}$ The prevalence of vitamin $\mathrm{D}$ deficiency is also significant in the general population, with reports suggesting that about one billion people worldwide have vitamin D deficiency. ${ }^{17}$ A low 25-hydroxyvitamin $\mathrm{D}$ level has been reported to be associated with obesity, hypertension, diabetes, MetS, and chronic vascular inflammation, even though there has been controversy surrounding these associations. ${ }^{18-21}$ Several explanations have been suggested for the role of vitamin D in the MetS-related components (Fig. 1). ${ }^{22-30}$ Vitamin D deficiency affects the components of MetS by affecting various variables such as nitric oxide, interleukin (IL)-6, IL-1 and so on.

As a result, vitamin $\mathrm{D}$ deficiencies and MetS often appear to be intertwined. Therefore, it is recommended that vitamin D intake be used in the treatment of MetS, but the effect of vitamin D supplementation on MetS in patients with or without vitamin D deficiency is not completely clear. Furthermore, all the benefits of vitamin D supplementation in improving MetS factors are not an ac-

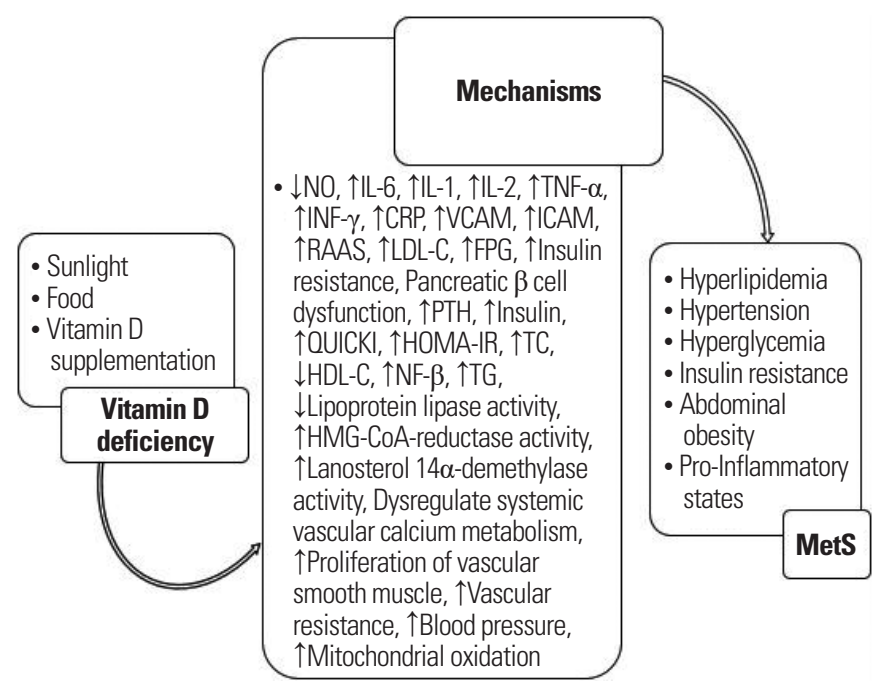

Figure 1. Overview of the role of vitamin D deficiency in metabolic syndrome (MetS) development. $\downarrow$, significant decrease; $\uparrow$, significant increase; NO, nitric oxide; IL, interleukin; TNF- $\alpha$, tumor necrosis factor alpha; INF- $\gamma$, interferon gamma; CRP, C-reactive protein; VCAM, vascular cell adhesion molecule; ICAM, intercellular adhesion molecule; RAAS, renin-angiotensin-aldosterone system; LDL-C, lowdensity lipoprotein cholesterol; FPG, fasting plasma glucose; PTH, parathyroid hormone; QUICKI, quantitative insulin sensitivity check index; HOMA-IR, homeostasis model assessment of insulin resistance; TC, total cholesterol; HDL-C, high-density lipoprotein cholesterol; NF- $\beta$, nuclear factor beta; TG, triglyceride; HMG-CoA, 3-hydroxy-3-methylglutaryl-coenzyme A.

ceptable justification for supplementation among patients with sufficient vitamin D levels. Therefore, there is a need for studies with appropriate design to find differences between the effects of vitamin D on people with different levels of vitamin D. To address this need, we sought to determine the effect of vitamin $\mathrm{D}$ deficiency on each of the MetS components and its related mechanisms, based 
on randomized clinical trial studies in people with MetS with or without vitamin $\mathrm{D}$ deficiency (Table 2).

\section{VITAMIN D AND ABDOMINAL OBESITY}

Vitamin D might affect obesity-associated inflammation and adi-

Table 2. All randomized controlled trial studies about the effect of different doses of vitamin D supplementation in patients with MetS

\begin{tabular}{|c|c|c|c|c|c|c|c|}
\hline Author (year) & $\begin{array}{c}\text { Study } \\
\text { population }\end{array}$ & $\begin{array}{l}\text { Duration } \\
\text { (mo) }\end{array}$ & Outcome measurement & Study design & $\begin{array}{l}\text { Vitamin D level at } \\
\text { baseline }\end{array}$ & $\begin{array}{l}\text { Vitamin D level at } \\
\text { the end of study }\end{array}$ & Result \\
\hline \multirow[t]{2}{*}{$\begin{array}{l}\text { Salekzamani et al. } \\
(2016)^{27}\end{array}$} & \multirow[t]{2}{*}{80} & \multirow[t]{2}{*}{4} & \multirow{2}{*}{$\begin{array}{l}\text { FPG, HOMA-IR, QUICKI, LDL-C, } \\
\text { HDL-C, TG, TC, dietary intake, } \\
\text { sun exposure, weight, BMI, FP, } \\
\text { WC, HC, SBP, DBP, WHtR }\end{array}$} & $\begin{array}{l}\text { Intervention group: 50,000 } \\
\text { IU/wk vitamin } D(n=40)\end{array}$ & $\begin{array}{l}16.45 \pm 15.50 \\
\mathrm{nmol} / \mathrm{L}\end{array}$ & $\begin{array}{l}78.38 \pm 21.71 \\
\mathrm{nmol} / \mathrm{L}\end{array}$ & \multirow[t]{2}{*}{ Intervention group: $\downarrow T G$} \\
\hline & & & & $\begin{array}{l}\text { Control group: placebo } \\
(\mathrm{n}=40)\end{array}$ & $\begin{array}{l}23.47 \pm 21.34 \\
\mathrm{nmol} / \mathrm{L}\end{array}$ & $\begin{array}{l}21.46 \pm 17.74 \\
\mathrm{nmol} / \mathrm{L}\end{array}$ & \\
\hline \multirow[t]{2}{*}{$\begin{array}{l}\text { Mahmood et al. } \\
(2016)^{24}\end{array}$} & \multirow[t]{2}{*}{$\begin{array}{c}\text { Not } \\
\text { mentioned }\end{array}$} & \multirow[t]{2}{*}{6} & \multirow[t]{2}{*}{$\begin{array}{l}\text { SBP, DBP, vitamin D, FPG, insulin, } \\
\text { HOMA, QUICKI, BMI, WC }\end{array}$} & $\begin{array}{l}\text { Intervention group: oral } \\
25(\mathrm{OH}) \text { D3 supplement } \\
60,000 \text { (IU) per week for } \\
8 \text { weeks followed by } \\
60,000 \text { IU monthly for } \\
4 \text { months }\end{array}$ & $15.4 \pm 9.03 \mathrm{ng} / \mathrm{mL}$ & $26.1 \pm 11.8 \mathrm{ng} / \mathrm{mL}$ & \multirow[t]{2}{*}{$\begin{array}{l}\text { Intervention group: } \downarrow W C \\
\downarrow \text { BMl } \\
\text { Control group: } \uparrow \text { insulin, } \\
\downarrow \text { QUICKI }\end{array}$} \\
\hline & & & & Control group: placebo & - & - & \\
\hline \multirow[t]{3}{*}{$\begin{array}{l}\text { Wongwiwatthananukit } \\
\text { et al. }(2013)^{29}\end{array}$} & \multirow[t]{3}{*}{90} & \multirow[t]{3}{*}{2} & \multirow{3}{*}{$\begin{array}{l}\text { WC, SBP, DBP, FPI, 25(OH)D, } \\
\text { calcium, HDL-C, HOMA-IR, } \\
\text { LDL-C, TC, TG, FPG }\end{array}$} & $\begin{array}{l}\text { (1) } 40,000 \text { IU/wk vitamin } D_{2} \\
(n=30)\end{array}$ & $\begin{array}{l}14.29 \pm 3.35 \\
\mathrm{ng} / \mathrm{mL}\end{array}$ & $\begin{array}{l}30.03 \pm 6.97 \\
\mathrm{ng} / \mathrm{mL}\end{array}$ & \multirow{3}{*}{$\begin{array}{l}\text { No positive effect of } \\
\text { vitamin } D_{2} \text { on } \\
\text { metabolic risk factors }\end{array}$} \\
\hline & & & & $\begin{array}{l}\text { (2) } 20,000 \text { IU/wk vitamin } D_{2} \\
(n=30)\end{array}$ & $\begin{array}{c}15.08 \pm 3.16 \\
\mathrm{ng} / \mathrm{mL}\end{array}$ & $\begin{array}{c}26.80 \pm 6.37 \\
\mathrm{ng} / \mathrm{mL}\end{array}$ & \\
\hline & & & & $\begin{array}{l}\text { (3) Control group: placebo } \\
(n=30)\end{array}$ & $\begin{array}{c}16.20 \pm 2.99 \\
\mathrm{ng} / \mathrm{mL}\end{array}$ & $\begin{array}{l}18.99 \pm 6.71 \\
\mathrm{ng} / \mathrm{mL}\end{array}$ & \\
\hline \multirow[t]{2}{*}{$\begin{array}{l}\text { Salekzamani et al. } \\
(2017)^{26}\end{array}$} & \multirow[t]{2}{*}{80} & \multirow[t]{2}{*}{4} & \multirow[t]{2}{*}{$\begin{array}{l}\text { IL-6, E-selectin, BMI, FPG, SBP, } \\
\text { DBP, weight, FM, FFM, TBW, } \\
\text { TG, HsCRP, sun exposure, PA, } \\
\text { VCAM-1, cCIMT, calcium }\end{array}$} & $\begin{array}{l}\text { Intervention group: } 50,000 \\
\text { IU/week vitamin D } \\
(n=40)\end{array}$ & $\begin{array}{c}13.70 \mathrm{nmol} / \mathrm{L} \\
(0.00-25.50)\end{array}$ & $\begin{array}{l}80 \mathrm{nmol} / \mathrm{L} \\
(67.25-90.50)\end{array}$ & \multirow{2}{*}{$\begin{array}{c}\text { Intervention group: } \downarrow \| L-6 \\
\uparrow \text { calcium, ( } \downarrow \text { E-selectin } \\
\text { and } \downarrow \text { VCAM- } 1 \text { but no } \\
\text { significant differences } \\
\text { between two groups) }\end{array}$} \\
\hline & & & & $\begin{array}{l}\text { Control group: placebo } \\
(n=40)\end{array}$ & $\begin{array}{l}19.97 \mathrm{nmol} / \mathrm{L} \\
(11.78-31.25)\end{array}$ & $\begin{array}{l}17.82 \mathrm{nmol} / \mathrm{L} \\
(13.07-28.50)\end{array}$ & \\
\hline \multirow[t]{2}{*}{ Kelishadi et al. (2014) ${ }^{23}$} & \multirow[t]{2}{*}{50} & \multirow[t]{2}{*}{3} & \multirow{2}{*}{$\begin{array}{l}\text { BMI, WC, WHtR, 25(OH)D, } \\
\text { insulin, FPG, HOMA-IR, TG, } \\
\text { MAP, LDL-C, HDL-C, TC, C-MetS }\end{array}$} & $\begin{array}{l}\text { Intervention group: } 300,000 \\
\text { IU/wk vitamin } D(n=25)\end{array}$ & $\begin{array}{l}18.27 \pm 2.04 \\
\mathrm{ng} / \mathrm{mL}\end{array}$ & $\begin{array}{l}32.01 \pm 2.14 \\
\mathrm{ng} / \mathrm{mL}\end{array}$ & \multirow{2}{*}{$\begin{array}{l}\text { Intervention group: } \\
\downarrow \text { Insulin, } \downarrow \text { TG, } \\
\downarrow \text { HOMA-IR and } \\
\downarrow \text { C-MetS }\end{array}$} \\
\hline & & & & $\begin{array}{l}\text { Control group: placebo } \\
(\mathrm{n}=25)\end{array}$ & $\begin{array}{c}17.91 \pm 2.27 \\
\mathrm{ng} / \mathrm{mL}\end{array}$ & $\begin{array}{l}19.07 \pm 2.01 \\
\mathrm{ng} / \mathrm{mL}\end{array}$ & \\
\hline \multirow[t]{6}{*}{ Farag et al. $(2018)^{22}$} & \multirow[t]{6}{*}{180} & \multirow[t]{6}{*}{3} & \multirow{6}{*}{$\begin{array}{l}\text { Weight, BMI, WC, FPG, SBP, DBP, } \\
\text { TC, TG, LDL-C, HDL-C, vitamin D, } \\
\text { PA, vitamin C }\end{array}$} & $\begin{array}{l}\text { (1) Vitamin C group: } 500 \\
\text { mg/day vitamin C }(\mathrm{n}=30)\end{array}$ & Group 1: - & & \multirow{6}{*}{$\begin{array}{l}\text { Group } 1 \text { and } 2 \text { (more } \\
\text { influence compared to } \\
\text { vitamin D): } \downarrow T G \text {, and } \\
\uparrow H D L-C \\
\text { Group } 3 \text { and } 4 \text { (more } \\
\text { influence compared to } \\
\text { vitamin C): } \downarrow F P G, \downarrow T C \text {, } \\
\downarrow L D L-C \text { and } \downarrow \text { blood } \\
\text { pressure }\end{array}$} \\
\hline & & & & $\begin{array}{l}\text { (2) Vitamin C plus PA group } \\
(n=30)\end{array}$ & Group 2: - & - & \\
\hline & & & & $\begin{array}{l}\text { (3) Vitamin D group: } 2,000 \\
\text { IU/day vitamin } D(n=30)\end{array}$ & $\begin{array}{l}\text { Group 3: } 10.8 \pm \\
2.8 \mathrm{ng} / \mathrm{mL}\end{array}$ & $23.2 \pm 4.9 \mathrm{ng} / \mathrm{mL}$ & \\
\hline & & & & $\begin{array}{l}\text { (4) Vitamin D plus PA group } \\
(n=30)\end{array}$ & $\begin{array}{l}\text { Group } 4 \text { : } 10.4 \pm \\
3.2 \mathrm{ng} / \mathrm{mL}\end{array}$ & $29 \pm 5.5 \mathrm{ng} / \mathrm{mL}$ & \\
\hline & & & & $\begin{array}{l}\text { (5) Placebo plus PA group } \\
(n=30)\end{array}$ & $\begin{array}{l}\text { Group 5: } 12.2 \pm 4 \\
\text { ng/mL }\end{array}$ & $12.6 \pm 4 \mathrm{ng} / \mathrm{mL}$ & \\
\hline & & & & $\begin{array}{l}\text { (6) Control group: placebo } \\
(n=30)\end{array}$ & $\begin{array}{l}\text { Group 6:11 } \pm 4 \\
\text { ng/mL }\end{array}$ & $18.9 \pm 4.5 \mathrm{ng} / \mathrm{mL}$ & \\
\hline \multirow[t]{3}{*}{$\begin{array}{l}\text { Sansanayudh et al. } \\
(2014)^{28}\end{array}$} & \multirow[t]{3}{*}{90} & \multirow[t]{3}{*}{2} & \multirow[t]{3}{*}{ 25(OH)D, calcium, OTC } & $\begin{array}{l}\text { (1) Control group: } 2 \text { capsules } \\
\text { of placebo/wk }(n=30)\end{array}$ & $16.2 \pm 3.0 \mathrm{ng} / \mathrm{mL}$ & $19.0 \mathrm{ng} / \mathrm{mL}$ & Group 2 and $3: \uparrow 25(\mathrm{OH}) \mathrm{D}$ \\
\hline & & & & $\begin{array}{l}\text { (2) Ergocalciferol 20,000 } \\
\text { IU/wk }(\mathrm{n}=30)\end{array}$ & $15.1 \pm 3.2 \mathrm{ng} / \mathrm{mL}$ & $26.8 \mathrm{ng} / \mathrm{mL}$ & \\
\hline & & & & $\begin{array}{l}\text { (3) Ergocalciferol 40,000 } \\
\text { IU/wk }(n=30)\end{array}$ & $14.3 \pm 3.4 \mathrm{ng} / \mathrm{mL}$ & $30.0 \mathrm{ng} / \mathrm{mL}$ & \\
\hline Yin et al. $(2016)^{30}$ & 126 & 12 & $\begin{array}{l}\text { BMI, WC, FPG, SBP, DBP, LDL-C, } \\
\text { HDL-C, PTH, 25(OH)D, }\end{array}$ & $\begin{array}{l}\text { Intervention group: } 700 \mathrm{IU} / \\
\text { day vitamin } \mathrm{D}(\mathrm{n}=63)\end{array}$ & $14.6 \pm 2.18 \mathrm{ng} / \mathrm{mL}$ & $33.1 \pm 4.37 \mathrm{ng} / \mathrm{mL}$ & Intervention group: $\downarrow$ PTH \\
\hline & & & HOMA-IR, QUICKI, FPI & $\begin{array}{l}\text { Control group: placebo } \\
(\mathrm{n}=63)\end{array}$ & $14.2 \pm 2.55 \mathrm{ng} / \mathrm{mL}$ & $14.6 \pm 2.80 \mathrm{ng} / \mathrm{mL}$ & \\
\hline
\end{tabular}


Table 2. Continued

\begin{tabular}{|c|c|c|c|c|c|c|c|}
\hline Author (year) & $\begin{array}{c}\text { Study } \\
\text { population }\end{array}$ & $\begin{array}{l}\text { Duration } \\
\text { (mo) }\end{array}$ & Outcome measurement & Study design & $\begin{array}{l}\text { Vitamin D level at } \\
\text { baseline }\end{array}$ & $\begin{array}{l}\text { Vitamin D level at } \\
\text { the end of study }\end{array}$ & Result \\
\hline \multirow[t]{2}{*}{ Makariou et al. $(2017)^{25}$} & \multirow[t]{2}{*}{50} & \multirow[t]{2}{*}{3} & \multirow[t]{2}{*}{$\begin{array}{l}\text { Weight, BMI, SBP, DBP, WC, TC, } \\
\text { TG, LDL-C, HDL-C, Apo A1, } \\
\text { Apo B, FPG, FPI, HOMA index* } \\
\text { HbA1c, PTH, 25(OH)D }\end{array}$} & $\begin{array}{l}\text { Intervention group: dietary } \\
\text { instructions }(-500 \mathrm{kcal} / \\
\text { day) plus } 2,000 \mathrm{IU} / \text { day } \\
\text { vitamin } \mathrm{D}(\mathrm{n}=25)\end{array}$ & $\begin{array}{c}16.0 \mathrm{ng} / \mathrm{mL} \\
(3.0-35.0)\end{array}$ & $\begin{array}{r}30.6 \mathrm{ng} / \mathrm{mL} \\
(8.4-67.0)\end{array}$ & \multirow[t]{2}{*}{ Intervention group: $\downarrow S B P$} \\
\hline & & & & $\begin{array}{l}\text { Control group: dietary } \\
\text { instructions }(-500 \mathrm{kcal} / \\
\text { day) }(\mathrm{n}=25)\end{array}$ & $\begin{array}{r}10.0 \mathrm{ng} / \mathrm{mL} \\
(4.0-39.6)\end{array}$ & $\begin{array}{r}13.0 \mathrm{ng} / \mathrm{mL} \\
(3.5-37.0)\end{array}$ & \\
\hline
\end{tabular}

*HOMA index = fasting insulin $\times$ fasting glucose/405.

MetS, metabolic syndrome; FPG, fasting plasma glucose; HOMA-IR, homeostasis model assessment of insulin resistance; QUICKI, quantitative insulin sensitivity check index; LDL-C, low-density lipoprotein cholesterol; HDL-C, high-density lipoprotein cholesterol; TG, triglyceride; TC, total cholesterol; BMl, body mass index; FP, body fat percent; WC, waist circumference; HC, hip circumference; SBP, systolic blood pressure; DBP, diastolic blood pressure; WHtR, waist-to-height ratio; $\downarrow$, significant decrease; $\uparrow$, significant increase; HOMA, homeostasis model assessment; 25(OH)D, 25-hydroxyvitamin D; FPI, fasting plasma insulin; IL, interleukin; FM, fat mass; FFM, fat-free mass; TBW, total body water; HsCRP, high-sensitivity C-reactive protein; PA, physical activity; VCAM-1, vascular cell adhesion molecule-1; cCIMT, common carotid intima-media thickness; MAP, mean arterial blood pressure; CMetS, continuous metabolic syndrome; QTc, corrected QT interval; PTH, parathyroid hormone; Apo, apolipoprotein; HbA1c, glycosylated hemoglobin.

posity. Obesity has recently emerged as a public health issue of pandemic proportions. ${ }^{31,32}$ Abdominal obesity is the most frequently observed component of MetS. ${ }^{33,34}$ Based on several studies, vitamin $\mathrm{D}$ levels are lower in most obese and overweight people, compared to people of normal weight who have less body fat, and obesity can increase the risk of vitamin $\mathrm{D}$ deficiency. ${ }^{35}$ Fat accumulation via increasing oxidative stress ${ }^{36}$ can increase the expression of nicotinamide adenine dinucleotide phosphate oxidase, decrease the expression of anti-oxidative enzymes, impair glucose uptake in muscle and adipose tissue, decrease insulin secretion from pancreatic $\beta$ cells, and affect oxidative phosphorylation, glyceraldehyde auto-oxidation, and protein kinase $\mathrm{C}$ activation. ${ }^{37-40}$

Macrophages within the adipose tissue secrete adipocytokines, such as plasminogen activator inhibitor-1 (PAI-1), tumor necrosis factor alpha (TNF- $\alpha)$, resistin, leptin, and adiponectin. PAI-1 leads to thrombosis and insulin resistance. ${ }^{37,41,42}$ TNF- $\alpha$ can phosphorylate and inactivate insulin receptors in the adipose tissue and smooth muscle cells, induce lipolysis, and inhibit adiponectin release, ${ }^{43}$ leading to insulin resistance and atherosclerosis. Several studies have demonstrated that levels of IL-6 and C-reactive protein (CRP) are high with MetS, and increased production of IL-6 and CRP results in increases in obesity and insulin resistance. ${ }^{44}$ Vitamin $\mathrm{D}$ through binding to its receptors in monocytes can reduce inflammatory cytokines such as CRP and lead to a reduction in systemic inflammation. ${ }^{45}$ In addition, receptors of vitamin $\mathrm{D}$ are located in the nucleus of macrophages, which produce cytokines such as TNF- $\alpha$. Vitamin $\mathrm{D}$ inhibits the protein expression of nuclear factor beta (NF- $\beta$ ), which has an important effect on the expression of TNF- $\alpha . .^{35}$

In several studies, the effect of different doses of vitamin $\mathrm{D}$ on body composition has been investigated in patients with MetS. ${ }^{22-}$ 25,27,29,30 In only one of these studies, conducted by Mahmood et al., ${ }^{24}$ vitamin D supplementation of 50,000 IU/wk decreased waist circumference (WC) and body mass index (BMI) in adults with MetS after 6 months. In this study, the group that received vitamin $\mathrm{D}$ supplementation experienced a significant decrease in $\mathrm{WC}$ and BMI $(P=0.001)$ at the end of the study.

In another study, 63 overweight or obese women were assigned to two groups, where intervention group received $600 \mathrm{mg}$ calcium and $200 \mathrm{IU} /$ day vitamin D and the placebo group received a placebo along with a $700 \mathrm{kcal} /$ day energy-deficit diet. This study by Major et al. ${ }^{46}$ showed that supplementation with calcium and vitamin $\mathrm{D}$ for 15 weeks affected WC.

In the study by Makariou et al., ${ }^{25}$ weight was reduced by about 1-2 kg after 3 months in both the intervention and control groups, which received dietary instructions $(-500 \mathrm{kcal} /$ day from usual intake) with or without 2,000 IU/day vitamin D, respectively. It seems this weight loss is due to the reduction in energy intake in both groups and not the vitamin D supplementation. In another study comparing groups with or without vitamin $\mathrm{D}$ deficiency ( $<20 \mathrm{ng} / \mathrm{mL}$ ),vitamin $\mathrm{D}$ deficiency was associated with higher systolic 24-hour ambulatory blood pressure monitoring (ABPM) $(P=0.01)$, daytime ABPM $(P=0.02)$, and body fat mass. ${ }^{47}$ In order to reach a definite conclusion, studies with stronger methods are needed to evaluate the effects of vitamin D supplementation on 
body composition in patients with MetS.

\section{VITAMIN D AND HYPERTENSION}

Studies have shown that MetS is more frequently observed in hypertensive populations. ${ }^{48}$ Increases in plasma volume and cardiac output can lead to peripheral vascular resistance as an important factor in the pathogenesis of hypertension. In turn, increased vascular resistance can result in severe insulin resistance and hyperinsulinemia, leading to a defective cycle. This condition can occur in obesity-related hypertension. ${ }^{49}$ Several studies have demonstrated that insufficient levels of vitamin D can increase the risk of hypertension and obesity. ${ }^{35}$

Obesity-related MetS is an inflammatory state..$^{50}$ Several inflammatory factors have been associated with obesity and other complications such as hypertension in obesity-associated MetS. ${ }^{51}$ It should be noted that various epidemiological studies have shown a positive association between IL-6 and blood pressure, atherosclerosis, and cardiovascular disease. ${ }^{12}$

Oxidative stress caused by adiposity can affect vascular wall cells directly and cause hypertension and atherosclerosis as MetS outcomes. ${ }^{37}$ The relationship between insulin resistance and hypertension is clear. ${ }^{52}$ Insulin has two roles in hypertension, as a vasodilator and as a factor in sodium reabsorption in the kidney. The setting of insulin resistance destroys the vasodilator role but cannot affect the sodium reabsorption. ${ }^{53}$

In some studies, the effect of vitamin $\mathrm{D}$ on the improvement of endothelial function has been shown. ${ }^{54,55}$ Vitamin D can participate in the pathogenesis of hypertension through several mechanisms, such as reducing the production of proinflammatory cytokines, decreasing renin-angiotensin-aldosterone system activity, and lowering parathyroid hormone levels. ${ }^{56}$

In a meta-analysis by $\mathrm{Wu}$ et al., ${ }^{57}$ which included four intervention studies, vitamin D significantly reduced systolic blood pressure (SBP) by about $2.44 \mathrm{mmHg}$, but it had no effect on diastolic blood pressure (DBP). However, other meta-analyses indicated that vitamin D supplementation does not affect either SBP or DBP. ${ }^{57}$ In another meta-analysis in 2018 by Shu and Huang ${ }^{58}$ on subjects with vitamin $\mathrm{D}$ deficiency, vitamin $\mathrm{D}$ supplementation resulted in a significant decrease in SBP but not in DBP.
In one randomized controlled trial by Makariou et al. ${ }^{25}$ in 25 patients with MetS, a hypocaloric diet (-500 kcal/day) plus 2,000 IU/day vitamin D supplements significantly changed SBP. In this study, SBP decreased about $3.7 \%$ in the intervention group $(P=0.05)$, whereas it was reduced about $1.5 \%$ in the placebo group. In this study, baseline vitamin D levels were $16.0 \mathrm{ng} / \mathrm{mL}(3.0-35.0 \mathrm{ng} / \mathrm{mL})$ and $10.0 \mathrm{ng} / \mathrm{mL}(4.0-39.6 \mathrm{ng} / \mathrm{mL})$ in the intervention and placebo groups, respectively.

In 2018, Farag et al..$^{22}$ studied 180 patients with MetS who were assigned to six groups. The first group received a $500 \mathrm{mg} /$ day supplement of vitamin C. The second group received vitamin C (500 $\mathrm{mg} /$ day) plus $30 \mathrm{~min} /$ day physical activity. The third group received $2,000 \mathrm{IU} /$ day supplements of vitamin $\mathrm{D}$. The fourth group received a 2,000 IU/day supplement of vitamin D along with $30 \mathrm{~min} /$ day physical activity. The placebo group received a placebo with $30 \mathrm{~min} /$ day physical activity. The control group received a placebo without any physical activity. After 3 months intervention, results showed that vitamin D supplementation has more influence on SBP and DBP compared to vitamin C. SBP decreased from $127.1 \pm 11.5 \mathrm{mmHg}$ to $121.3 \pm 9.2 \mathrm{mmHg}$ (mean change $-5.8 \pm 7.1 \mathrm{mmHg}$ ), and DBP increased from $79.8 \pm 9.5 \mathrm{mmHg}$ to $80.1 \pm 5.8 \mathrm{mmHg}$ (mean change $1 \pm 6.9 \mathrm{mmHg}$ ) in the vitamin $\mathrm{D}$ group. Meanwhile, in the vitamin $D$ plus physical activity group, SBP decreased from $129 \pm 12.7 \mathrm{mmHg}$ to $126.2 \pm 8.9 \mathrm{mmHg}$, and DBP changed from $83.6 \pm 9.4 \mathrm{mmHg}$ at baseline to $81.7 \pm 5.3 \mathrm{mmHg}$ after 3 months of intervention. The vitamin $\mathrm{D}$ levels in the vitamin $\mathrm{D}$ and vitamin $\mathrm{D}$ plus physical activity groups were $10.8 \pm 2.8 \mathrm{ng} / \mathrm{mL}$ and $10.4 \pm 3.2 \mathrm{ng} / \mathrm{mL}$, respectively, at the beginning of study. By comparing the significant decrease in blood pressure in the mentioned study with other studies that showed no effect of vitamin D supplementation on blood pressure, we noted that vitamin D supplementation may have a more positive effect in people with vitamin $\mathrm{D}$ deficiency than in people with insufficient vitamin D level. ${ }^{24,26,27,29,30}$

\section{VITAMIN D, HYPERGLYCEMIA, AND INSULIN RESISTANCE}

Hyperglycemia and insulin resistance are components of MetS., Patients with MetS are at increased risk for type 2 diabetes. ${ }^{59}$ Noting a low level of vitamin $\mathrm{D}$ in patients with MetS, ${ }^{60}$ studies have 
demonstrated that restoration of serum 25-hydroxyvitamin D levels can improve insulin resistance. ${ }^{61}$ Diabetes is a type of inflammatory disease, and vitamin $\mathrm{D}$ has anti-inflammatory effects, so it follows that vitamin $\mathrm{D}$ could be useful in improving islet cell function, insulin release, and insulin resistance. ${ }^{62}$

In 2016, Mahmood et al. ${ }^{24}$ designed a study to assess the effects of vitamin D supplements on insulin resistance in patients with MetS who have low vitamin D intake. The intervention group consumed 60,000 IU/wk vitamin D during the first 8 weeks, followed by $60,000 \mathrm{IU} / \mathrm{mo}$ over the next 4 months, and the control group consumed a placebo for 6 months. At the end of 6 months, mean insulin levels increased significantly from $10.7 \pm 4.81 \mathrm{IU} / \mathrm{L}$ to $15.4 \pm$ 14.0 IU/L $(P=0.03)$, but the mean quantitative insulin sensitivity check index (QUICKI) decreased significantly from $0.34 \pm 0.03$ to $0.32 \pm 0.03$ in the placebo group $(P=0.02)$. After 6 months, there were no significant changes in the intervention group, except in serum vitamin $\mathrm{D}, \mathrm{WC}$, and BMI. Serum vitamin $\mathrm{D}$ increased significantly from $15.4 \pm 9.03 \mathrm{ng} / \mathrm{mL}$ to $26.1 \pm 11.8 \mathrm{ng} / \mathrm{mL}(P<0.0001)$, WC changed from $95.9 \pm 6.66 \mathrm{~cm}$ to $94.6 \pm 7.47 \mathrm{~cm}(P=0.001)$, and BMI decreased from $29.1 \pm 4.06 \mathrm{~kg} / \mathrm{m}^{2}$ to $28.5 \pm 4.16 \mathrm{~kg} / \mathrm{m}^{2}$ $(P=0.001)$. In another randomized controlled trial in 2014, Kelishadi et al. ${ }^{23}$ demonstrated that 12 weeks supplementation with $300,000 \mathrm{IU} /$ wk vitamin D in 25 children with MetS resulted in decreased insulin and homeostasis model assessment of insulin resistance (HOMA-IR) compared with the baseline $(P=0.04)$ and with the placebo group $(P=0.02)$. Insulin changed from $14.27 \pm$ $1.32 \mu \mathrm{IU} / \mathrm{L}$ to $13.71 \pm 1.58 \mu \mathrm{IU} / \mathrm{L}$, and HOMA-IR decreased from $3.21 \pm 0.11$ to $2.81 \pm 0.25$ compared with the baseline. In both Mahmood et al..$^{24}$ and Kelishadi et al. ${ }^{23}$ studies, patients in the intervention group had insufficient levels of vitamin D (5.4 \pm 9.03 and $18.27 \pm 2.04 \mathrm{ng} / \mathrm{mL}$, respectively). The controversy in results is probably due to the use of a high dose of vitamin D in the Kelishadi et al. $^{23}$ study, compared to the other study.

Farag et al. $^{22}$ aimed to determine the effect of supplementation of vitamin $\mathrm{D}$ and vitamin $\mathrm{C}$ on MetS patients. In this study, the results showed that 3 months intervention could decrease fasting plasma glucose $(\mathrm{FPG})$ in the vitamin $\mathrm{D}(\mathrm{n}=30)$ and vitamin $\mathrm{D}$ plus physical activity $(\mathrm{n}=30)$ groups, and vitamin $\mathrm{D}$ had more of an effect on FPG than did vitamin C. FPG decreased from $108 \pm 17.1 \mathrm{mg} / \mathrm{dL}$ at baseline to $97.8 \pm 7.7 \mathrm{mg} / \mathrm{dL}$ in the vitamin $\mathrm{D}$ group and changed from $106 \pm 11.8 \mathrm{mg} / \mathrm{dL}$ to $97.7 \pm 8.7 \mathrm{mg} / \mathrm{dL}$ in the vitamin $\mathrm{D}$ plus $30 \mathrm{~min} /$ day physical activity group.

The HOMA, QUICKI, HOMA-IR, FPG, and fasting plasma insulin are the parameters that were measured in recent studies, which assessed the effect of vitamin D supplements in patients with MetS. ${ }^{22-25,27,29,30}$ Most of these studies showed no significant effect of vitamin D on the mentioned parameters; therefore, further clinical trials in patients with prediabetes and diabetes are needed to test the hypothesis that vitamin $\mathrm{D}$ deficiency exacerbates these diseases, and vitamin D supplementation would improve it.

\section{VITAMIN D AND HYPERLIPIDEMIA}

Patients with MetS have postprandial lipemia (PPL). ${ }^{63} \mathrm{PPL}$ is characterized by the secretion of triglyceride (TG)-rich lipoproteins. When these lipoproteins accumulate, they can affect activation of systemic leukocytes, impair endothelial cell function, promote the development of atherogenic low-density lipoprotein cholesterol (LDL-C) particles, reduce the concentration of high-density lipoprotein cholesterol (HDL-C), and increase the accumulation of atherogenic lipoproteins, which leads to oxidative stress and inflammation. ${ }^{64,65}$ Several studies have indicated an inverse association between vitamin $\mathrm{D}$ and serum lipid profile. ${ }^{66}$ In a meta-analysis conducted by Wang et al. ${ }^{67}$ of 10 randomized clinical trials regarding the influence of vitamin D supplementation on plasma lipid profile, vitamin D supplementation increased LDL-C concentration by about $3.23 \mathrm{mg} / \mathrm{dL}$, but did not significantly affect total cholesterol (TC) (increased by $1.52 \mathrm{mg} / \mathrm{dL}$ ), HDL-C (decreased by $0.14 \mathrm{mg} / \mathrm{dL}$ ), or TG (decreased by $1.92 \mathrm{mg} / \mathrm{dL}$ ). In a study by Jorde et al.$^{68}$ that included 8,018 nonsmoking and 2,087 smoking subjects, direct associations were observed between serum vitamin D and TC, HDL-C, and LDL-C, but the associations between vitamin $\mathrm{D}$ and the LDL$\mathrm{C}$ to $\mathrm{HDL}-\mathrm{C}$ ratio and between vitamin $\mathrm{D}$ and $\mathrm{TG}$ were negative. The purpose of this study was to determine the association between serum 25-hydroxyvitamin D and serum lipid profile.

Although the effect of vitamin D on lipid metabolism is known, its mechanisms are still unknown. ${ }^{69}$ Several studies have shown that vitamin $\mathrm{D}$ plays direct and indirect roles in altering lipid profile by affecting lipid metabolism. ${ }^{70}$ Vitamin D can (1) increase the activity of lipoprotein lipase in adipose tissue; ${ }^{71}(2)$ alter gene expression in 
$\mathrm{C} 2 \mathrm{C} 12$ cells through effects on proliferation, differentiation, and myotube size; ${ }^{72}$ (3) improve cytokines, ${ }^{73}$ the immune system, ${ }^{74}$ arterial stiffness, ${ }^{75}$ inflammation, ${ }^{76}$ phospholipid metabolism, and mitochondrial oxidation; ${ }^{77,78}$ (4) reduce3-hydroxy-3-methylglutaryl-coenzyme A reductase and lanosterol $14 \alpha$-demethylase enzyme activity; ${ }^{79}$ and (5) have anti-atherogenic and anti-inflammatory potency. ${ }^{80,81}$

In the study conducted by Hirschler et al., ${ }^{82}$ supplementation of $5,000 \mathrm{IU} / \mathrm{wk}$ of vitamin D for 8 weeks in children with vitamin D deficiency decreased the prevalence of low HDL-C in the intervention group from $35.7 \%$ to $5.7 \%$ after 1 -year follow-up $(P<0.01)$. In this study, HDL-C increased from $38 \pm 7 \mathrm{mg} / \mathrm{dL}$ at baseline to $46 \pm$ $7 \mathrm{mg} / \mathrm{dL}$ after lyear.In another study on children 6-10 years of age, the relationship between vitamin $\mathrm{D}$ and lipid profile was shown. ${ }^{83}$ Sixty children (29 males) used 100,000 IU/mo of vitamin D, and 36 children used 50,000 IU/mo for 2 months. The mean HDL-C increased significantly in the group that received 100,000 IU of vita$\min \mathrm{D}$, from $39.8 \mathrm{mg} / \mathrm{dL}$ to $43.9 \mathrm{mg} / \mathrm{dL}$, while HDL-C increased non-significantly from $44.4 \mathrm{mg} / \mathrm{dL}$ to $45.1 \mathrm{mg} / \mathrm{dL}$ in the group that received 50,000 IU of vitamin D. No significant changes were found in the median values of TG (117 vs. $111 \mathrm{mg} / \mathrm{dL}$ ) and TG/ HDL-C (3.0 vs. $2.7 \mathrm{mg} / \mathrm{dL}$ ) in the group that received 100,000 IU of vitamin D, but TG (95-111 mg/dL) and TG/HDL-C (2.2-2.4 $\mathrm{mg} / \mathrm{dL}$ ) increased significantly in the group that received 50,000 IU of vitamin D. ${ }^{81}$ Islam et al. ${ }^{84}$ showed that in patients who underwent one year of vitamin $\mathrm{D}$ supplementation, there were no significant changes in the TC, LDL-C, HDL-C, or in the LDL-C to HDL-C ratio. It should be noted that in this study, 200 healthy subjects aged 16-36 years with hypovitaminosis D were assigned into four groups. The first group received vitamin D supplements (400 IU/day), the second group received vitamin D plus calcium lactate $(600 \mathrm{mg})$, the third group received multiple micronutrients, vitamin $\mathrm{D}$, and calcium lactate, and the last group received a placebo.

Salekzamani et al. ${ }^{27}$ showed that TG levels in patients with MetS were significantly reduced after consumption of 50,000 IU/wk of vitamin $\mathrm{D}$ for 12 weeks. No other changes were observed between the two groups in this study. Before the intervention, TG levels were $269 \pm 97 \mathrm{mg} / \mathrm{dL}$ and significantly decreased to $242 \pm 82 \mathrm{mg} / \mathrm{dL}$ at the end of study, but it increased from $185 \pm 61 \mathrm{mg} / \mathrm{dL}$ to $196 \pm 72$ $\mathrm{mg} / \mathrm{dL}$ in the placebo group. Farag et al. ${ }^{22}$ in 2018 designed a ran- domized controlled study on 180 patients with MetS. In this study, TC and LDL-C levels decreased significantly in groups that received 2,000 IU/day vitamin $\mathrm{D}(\mathrm{n}=30)$ or 2,000 IU/day vitamin D plus physical activity $(\mathrm{n}=30)$. TC levels decreased from $173.5 \pm$ $60.8 \mathrm{mg} / \mathrm{dL}$ to $160.5 \pm 33.4 \mathrm{mg} / \mathrm{dL}$ and from $194.7 \pm 32.2 \mathrm{mg} / \mathrm{dL}$ to $81.7 \pm 31.3 \mathrm{mg} / \mathrm{dL}$ in the vitamin $\mathrm{D}$ and vitamin $\mathrm{D}$ plus physical activity groups, respectively. LDL-C levels decreased from $120.7 \pm$ $64.4 \mathrm{mg} / \mathrm{dL}$ to $107 \pm 36.6 \mathrm{mg} / \mathrm{dL}$ and from $149.6 \pm 35.8 \mathrm{mg} / \mathrm{dL}$ to $138.3 \pm 31.4 \mathrm{mg} / \mathrm{dL}$ in the vitamin $\mathrm{D}$ and vitamin $\mathrm{D}$ plus physical activity groups, respectively. Since vitamin D can affect the lipid profile, it follows that vitamin $\mathrm{D}$ could probably improve MetS factors. The patients in this study had vitamin D deficiency, and vitamin D supplements could affect their lipid profiles. However, in most studies which recruited patients with insufficient baseline levels of vitamin D, vitamin D supplements did not show any effect, ${ }^{24-26,29,30}$ although in only a few studies was a significant effect on the lipid profile seen. ${ }^{23,27}$

\section{CONCLUSION}

Across multiple studies, no consensus has been reached regarding the effect of vitamin D supplementation on the components of MetS. Although these studies did not yield similar results, the findings of the present study reported an inverse relationship between vitamin $\mathrm{D}$ supplementation and mentioned factors. MetS and vita$\min \mathrm{D}$ deficiency are prevalent today, and given the relatively modest price of vitamin $\mathrm{D}$ supplementation and the possible mechanisms by which it is suggested, vitamin D supplementation is recommended in people with vitamin $\mathrm{D}$ deficiency, even if it has no considerable effect on most MetS factors. However, existing data from interventional studies are insufficient to reach a definitive conclusion about the effect of vitamin D supplementation on MetS components in patients without vitamin D deficiency. Thus, new clinical studies are needed to test the hypothesis that vitamin D supplementation could alleviate MetS components in patients with MetS who consume sufficient amount of vitamin D.

\section{CONFLICTS OF INTEREST}

The authors declare no conflict of interest. 


\section{AUTHOR CONTRIBUTIONS}

Study concept and design: all authors; acquisition of data: SF; drafting of the manuscript: all authors; critical revision of the manuscript: all authors; and study supervision: MA.

\section{REFERENCES}

1. Lopes HF, Corrêa-Giannella ML, Consolim-Colombo FM, Egan BM. Visceraladiposity syndrome. Diabetol Metab Syndr 2016;8:40.

2. Prasad P, Kochhar A. Interplay of vitamin D and metabolic syndrome: a review. Diabetes Metab Syndr 2016;10:105-12.

3. Moazzen $\mathrm{H}$, Alizadeh M. Effects of pomegranate juice on cardiovascular risk factors in patients with metabolic syndrome: a double-blinded, randomized crossover controlled trial. Plant Foods Hum Nutr 2017;72:126-33.

4. Samson SL, Garber AJ. Metabolic syndrome. Endocrinol Metab Clin North Am 2014;43:1-23.

5. Kaur J. A comprehensive review on metabolic syndrome. Cardiol Res Pract 2014;2014:943162.

6. Amirkalali B, Fakhrzadeh H, Sharifi F, Kelishadi R, Zamani F, Asayesh $\mathrm{H}$, et al. Prevalence of metabolic syndrome and its components in the Iranian adult population: a systematic review and meta-analysis. Iran Red Crescent Med J 2015;17: e24723.

7. Saklayen MG. The global epidemic of the metabolic syndrome. Curr Hypertens Rep 2018;20:12.

8. Khayyatzadeh SS, Moohebati M, Mazidi M, Avan A, Tayefi M, Parizadeh SM, et al. Nutrient patterns and their relationship to metabolic syndrome in Iranian adults. Eur J Clin Invest 2016;46:840-52.

9. Nolan PB, Carrick-Ranson G, Stinear JW, Reading SA, Dalleck LC. Prevalence of metabolic syndrome and metabolic syndrome components in young adults: a pooled analysis. Prev Med Rep 2017;7:211-5.

10. Delavari A, Forouzanfar MH, Alikhani S, Sharifian A, Kelishadi R. First nationwide study of the prevalence of the metabolic syndrome and optimal cutoff points of waist circumference in the Middle East: the national survey of risk factors for non- communicable diseases of Iran. Diabetes Care 2009;32:1092-7.

11. Gluvic Z, Zaric B, Resanovic I, Obradovic M, Mitrovic A, Radak D, et al. Link between metabolic syndrome and insulin resistance. Curr Vasc Pharmacol 2017;15:30-9.

12. McCracken E, Monaghan M, Sreenivasan S. Pathophysiology of the metabolic syndrome. Clin Dermatol 2018;36:14-20.

13. Fiszman M, Rosemblat G, Ahlers CB, Rindflesch TC. Identifying risk factors for metabolic syndrome in biomedical text. AMIA Annu Symp Proc 2007;2007:249-53.

14. Srimani S, Saha I, Chaudhuri D. Prevalence and association of metabolic syndrome and vitamin D deficiency among postmenopausal women in a rural block of West Bengal, India. PLoS One 2017;12:e0188331.

15. Nair R, Maseeh A. Vitamin D: the "sunshine" vitamin. J Pharmacol Pharmacother 2012;3:118-26.

16. Zhang R, Naughton DP. Vitamin D in health and disease: current perspectives. Nutr J 2010;9:65.

17. Yu JR, Lee SA, Lee JG, Seong GM, Ko SJ, Koh G, et al. Serum vitamin $\mathrm{d}$ status and its relationship to metabolic parameters in patients with type 2 diabetes mellitus. Chonnam Med J 2012;48:108-15.

18. Vitezova A, Zillikens MC, van Herpt TT, Sijbrands EJ, Hofman A, Uitterlinden AG, et al. Vitamin D status and metabolic syndrome in the elderly: the Rotterdam Study. Eur J Endocrinol 2015;172:327-35.

19. Amirbaigloo A, Hosseinpanah F, Sarvghadi F, Tohidi M, Eskandary PS, Azizi F. Absence of association between vitamin $\mathrm{D}$ deficiency and incident metabolic syndrome: Tehran Lipid and Glucose Study. Metab Syndr Relat Disord 2013;11:23642.

20. Fung GJ, Steffen LM, Zhou X, Harnack L, Tang W, Lutsey $\mathrm{PL}$, et al. Vitamin D intake is inversely related to risk of developing metabolic syndrome in African American and white men and women over 20 y: the Coronary Artery Risk Development in Young Adults study. Am J Clin Nutr 2012;96: 24-9.

21. Khan H, Kunutsor S, Franco OH, Chowdhury R. Vitamin D, type 2 diabetes and other metabolic outcomes: a systematic review and meta-analysis of prospective studies. Proc Nutr Soc 2013;72:89-97. 
22. Farag HA, Hosseinzadeh-Attar MJ, Muhammad BA, Esmaillzadeh A, Bilbeisi AH. Comparative effects of vitamin D and vitamin $\mathrm{C}$ supplementations with and without endurance physical activity on metabolic syndrome patients: a randomized controlled trial. Diabetol Metab Syndr 2018;10:80.

23. Kelishadi R, Salek S, Salek M, Hashemipour M, Movahedian M. Effects of vitamin D supplementation on insulin resistance and cardiometabolic risk factors in children with metabolic syndrome: a triple-masked controlled trial. J Pediatr (Rio J) 2014;90:28-34.

24. Mahmood SF, Idiculla J, Joshi R, Joshi S, Kulkarni S. Vitamin $\mathrm{D}$ supplementation in adults with vitamin $\mathrm{D}$ deficiency and its effect on metabolic syndrome: a randomized controlled study. Int J Vitam Nutr Res 2016;86:121-6.

25. Makariou SE, Elisaf M, Challa A, Tentolouris N, Liberopoulos EN. No effect of vitamin D supplementation on cardiovascular risk factors in subjects with metabolic syndrome: a pilot randomised study. Arch Med Sci Atheroscler Dis 2017;2: e52-60.

26. Salekzamani S, Bavil AS, Mehralizadeh H, Jafarabadi MA, Ghezel A, Gargari BP. The effects of vitamin D supplementation on proatherogenic inflammatory markers and carotid intima media thickness in subjects with metabolic syndrome: a randomized double-blind placebo-controlled clinical trial. Endocrine 2017;57:51-9.

27. Salekzamani S, Mehralizadeh H, Ghezel A, Salekzamani Y, Jafarabadi MA, Bavil AS, et al. Effect of high-dose vitamin D supplementation on cardiometabolic risk factors in subjects with metabolic syndrome: a randomized controlled doubleblind clinical trial. J Endocrinol Invest 2016;39:1303-13.

28. Sansanayudh N, Wongwiwatthananukit S, Phetkrajaysang N, Krittiyanunt S. Comparative efficacy and safety of different doses of ergocalciferol supplementation in patients with metabolic syndrome. Int J Clin Pharm 2014;36:771-8.

29. Wongwiwatthananukit S, Sansanayudh N, Phetkrajaysang N, Krittiyanunt S. Effects of vitamin D(2) supplementation on insulin sensitivity and metabolic parameters in metabolic syndrome patients. J Endocrinol Invest 2013;36:558-63.

30. Yin X, Yan L, Lu Y, Jiang Q, Pu Y, Sun Q. Correction of hypovitaminosis $\mathrm{D}$ does not improve the metabolic syndrome risk profile in a Chinese population: a randomized controlled trial for 1 year. Asia Pac J Clin Nutr 2016;25:71-7.

31. Monsey MS, Gerhard DM. Obesity: introduction. Yale J Biol Med 2014;87:97-8.

32. Alizadeh M, Daneghian S, Ghaffari A, Ostadrahimi A, Safaeiyan A, Estakhri R, et al. The effect of hypocaloric diet enriched in legumes with or without $\mathrm{L}$-arginine and selenium on anthropometric measures in central obese women. J Res Med Sci 2010;15:331-43.

33. Alizadeh M, Gharaaghaji R, Gargari BP. The effects of legumes on metabolic features, insulin resistance and hepatic function tests in women with central obesity: a randomized controlled trial. Int J Prev Med 2014;5:710-20.

34. Mozaffarian D. Dietary and policy priorities for cardiovascular disease, diabetes, and obesity: a comprehensive review. Circulation 2016;133:187-225.

35. Khosravi ZS, Kafeshani M, Tavasoli P, Zadeh AH, Entezari MH. Effect of vitamin D supplementation on weight loss, glycemic indices, and lipid profile in obese and overweight women: a clinical trial study. Int J Prev Med 2018;9:63.

36. Marseglia L, Manti S, D’Angelo G, Nicotera A, Parisi E, Di Rosa G, et al. Oxidative stress in obesity: a critical component in human diseases. Int J Mol Sci 2014;16:378-400.

37. Furukawa S, Fujita T, Shimabukuro M, Iwaki M, Yamada Y, Nakajima Y, et al. Increased oxidative stress in obesity and its impact on metabolic syndrome. J Clin Invest 2004;114: 1752-61.

38. Matsuoka T, Kajimoto Y, Watada H, Kaneto H, Kishimoto M, Umayahara Y, et al. Glycation-dependent, reactive oxygen species-mediated suppression of the insulin gene promoter activity in HIT cells. J Clin Invest 1997;99:144-50.

39. Rudich A, Tirosh A, Potashnik R, Hemi R, Kanety H, Bashan N. Prolonged oxidative stress impairs insulin-induced GLUT4 translocation in 3T3-L1adipocytes. Diabetes 1998;47:1562-9.

40. Manna P, Jain SK. Obesity, oxidative stress, adipose tissue dysfunction, and the associated health risks: causes and therapeutic strategies. Metab Syndr Relat Disord 2015;13:423-44.

41. Yamauchi T, Kamon J, Waki H, Terauchi Y, Kubota N, Hara K, et al. The fat-derived hormone adiponectin reverses insulin resistance associated with both lipoatrophy and obesity. Nat 
Med 2001;7:941-6.

42. Okamoto Y, Kihara S, Ouchi N, Nishida M, Arita Y, Kumada $\mathrm{M}$, et al. Adiponectin reduces atherosclerosis in apolipoprotein E-deficient mice. Circulation 2002;106:2767-70.

43. Rochlani Y, Pothineni NV, Kovelamudi S, Mehta JL. Metabolic syndrome: pathophysiology, management, and modulation by natural compounds. Ther Adv Cardiovasc Dis 2017;11: 215-25.

44. Bastard JP, Jardel C, Bruckert E, Blondy P, Capeau J, Laville M, et al. Elevated levels of interleukin 6 are reduced in serum and subcutaneous adipose tissue of obese women after weight loss. J Clin Endocrinol Metab 2000;85:3338-42.

45. Foroughi M, Maghsoudi Z, Ghiasvand R, Iraj B, Askari G. Effect of vitamin D supplementation on C-reactive protein in patients with nonalcoholic fatty liver. Int J Prev Med 2014;5: 969-75.

46. Major GC, Alarie F, Doré J, Phouttama S, Tremblay A. Supplementation with calcium + vitamin D enhances the beneficial effect of weight loss on plasma lipid and lipoprotein concentrations. Am J Clin Nutr 2007;85:54-9.

47. Moreira JS, de Paula TP, Sperb LF, Miller ME, Azevedo MJ, Viana LV. Association of plasma vitamin D status with lifestyle patterns and ambulatory blood pressure monitoring parameters in patients with type 2 diabetes and hypertension. Diabetes Res Clin Pract 2018;139:139-46.

48. Pierdomenico SD, Cuccurullo F. Ambulatory blood pressure monitoring in type 2 diabetes and metabolic syndrome: a review. Blood Press Monit 2010;15:1-7.

49. Cabandugama PK, Gardner MJ, Sowers JR. The renin angiotensin aldosterone system in obesity and hypertension: roles in the cardiorenal metabolic syndrome. Med Clin North Am 2017;101:129-37.

50. de Heredia FP, Gómez-Martínez S, Marcos A. Obesity, inflammation and the immune system. Proc Nutr Soc 2012;71: $332-8$.

51. Cox AJ, West NP, Cripps AW. Obesity, inflammation, and the gut microbiota. Lancet Diabetes Endocrinol 2015;3:207-15.

52. Soleimani M. Insulin resistance and hypertension: new insights. Kidney Int 2015;87:497-9.

53. Horita S, Seki G, Yamada H, Suzuki M, Koike K, Fujita T. In- sulin resistance, obesity, hypertension, and renal sodium transport. Int J Hypertens 2011;2011:391762.

54. Sugden JA, Davies JI, Witham MD, Morris AD, Struthers AD. Vitamin D improves endothelial function in patients with type 2 diabetes mellitus and low vitamin D levels. Diabet Med 2008;25:320-5.

55. Tarcin O, Yavuz DG, Ozben B, Telli A, Ogunc AV, Yuksel M, et al. Effect of vitamin D deficiency and replacement on endothelial function in asymptomatic subjects. J Clin Endocrinol Metab 2009;94:4023-30.

56. Beveridge LA, Struthers AD, Khan F, Jorde R, Scragg R, Macdonald HM, et al. Effect of vitamin D supplementation on blood pressure: a systematic review and meta-analysis incorporating individual patient data. JAMA Intern Med 2015;175: 745-54.

57. Wu SH, Ho SC, Zhong L. Effects of vitamin D supplementation on blood pressure. South Med J 2010;103:729-37.

58. Shu L, Huang K. Effect of vitamin D supplementation on blood pressure parameters in patients with vitamin $\mathrm{D}$ deficiency: a systematic review and meta-analysis. J Am Soc Hypertens 2018; 12:488-96.

59. Nsiah K, Shang VO, Boateng KA, Mensah FO. Prevalence of metabolic syndrome in type 2 diabetes mellitus patients. Int J Appl Basic Med Res 2015;5:133-8.

60. von Hurst PR, Stonehouse W, Matthys C, Conlon C, Kruger MC, Coad J. Study protocol: metabolic syndrome, vitamin D and bone status in South Asian women living in Auckland, New Zealand: a randomised, placebo-controlled, double-blind vitamin D intervention. BMC Public Health 2008;8:267.

61. Takiishi T, Gysemans C, Bouillon R, Mathieu C. Vitamin D and diabetes. Endocrinol Metab Clin North Am 2010;39:419-46.

62. Wimalawansa SJ. Associations of vitamin D with insulin resistance, obesity, type 2 diabetes, and metabolic syndrome. J Steroid Biochem Mol Biol 2018;175:177-89.

63. Freese EC, Gist NH, Acitelli RM, McConnell WJ, Beck CD, Hausman DB, et al. Acute and chronic effects of sprint interval exercise on postprandial lipemia in women at-risk for the metabolic syndrome. J Appl Physiol (1985) 2015;118:872-9.

64. Kolovou GD, Anagnostopoulou KK, Pavlidis AN, Salpea KD, Iraklianou SA, Tsarpalis K, et al. Postprandial lipemia in men 
with metabolic syndrome, hypertensives and healthy subjects. Lipids Health Dis 2005;4:21.

65. Couillard C, Bergeron N, Bergeron J, Pascot A, Mauriège P, Tremblay A, et al. Metabolic heterogeneity underlying postprandial lipemia among men with low fasting high density lipoprotein cholesterol concentrations. J Clin Endocrinol Metab 2000;85:4575-82.

66. Jorde R, Grimnes G. Vitamin D and metabolic health with special reference to the effect of vitamin D on serum lipids. Prog Lipid Res 2011;50:303-12.

67. Wang H, Xia N, Yang Y, Peng DQ. Influence of vitamin D supplementation on plasma lipid profiles: a meta-analysis of randomized controlled trials. Lipids Health Dis 2012;11:42.

68. Jorde R, Figenschau Y, Hutchinson M, Emaus N, Grimnes G. High serum25-hydroxyvitamin D concentrations are associated with a favorable serum lipid profile. Eur J Clin Nutr 2010; 64:1457-64.

69. Fernández-Arroyo S, Hernández-Aguilera A, de Vries MA, Burggraaf B, van der Zwan E, Pouw N, et al. Effect of vitamin D3 on the postprandial lipid profile in obese patients: a nontargeted lipidomics study. Nutrients 2019;11:1194.

70. Hafez M, Musa N, Abdel Atty S, Ibrahem M, Abdel Wahab N. Effect of vitamin D supplementation on lipid profile in vitamin D-deficient children with type 1 diabetes and dyslipidemia. Horm Res Paediatr 2019;91:311-8.

71. Silvagno F, Pescarmona G. Spotlight on vitamin D receptor, lipid metabolism and mitochondria: some preliminary emerging issues. Mol Cell Endocrinol 2017;450:24-31.

72. Girgis CM, Clifton-Bligh RJ, Mokbel N, Cheng K, Gunton JE. Vitamin D signaling regulates proliferation, differentiation, and myotube size in $\mathrm{C} 2 \mathrm{C} 12$ skeletal muscle cells. Endocrinology 2014;155:347-57.

73. Zhang Y, Leung DY, Richers BN, Liu Y, Remigio LK, Riches DW, et al. Vitamin D inhibits monocyte/macrophage proinflammatory cytokine production by targeting MAPK phosphatase-1. J Immunol 2012;188:2127-35.

74. El-Fakhri N, McDevitt H, Shaikh MG, Halsey C, Ahmed SF. Vitamin D and its effects on glucose homeostasis, cardiovascular function and immune function. Horm Res Paediatr 2014; 81:363-78.
75. Klop B, van de Geijn GJ, Birnie E, Njo TL, Janssen HW, Jansen HG, et al. Vitamin D3 mediated effects on postprandial leukocyte activation and arterial stiffness in men and women. Eur J Clin Nutr 2014;68:635-7.

76. Querfeld U. Vitamin D and inflammation. Pediatr Nephrol 2013;28:605-10.

77. Boyan BD, Sylvia VL, Dean DD, Pedrozo H, Del Toro F, Nemere I, et al. 1,25- $(\mathrm{OH}) 2 \mathrm{D} 3$ modulates growth plate chondrocytes via membrane receptor-mediated protein kinase $\mathrm{C}$ by a mechanism that involves changes in phospholipid metabolism and the action of arachidonic acid and PGE2. Steroids 1999;64:129-36.

78. Sinha A, Hollingsworth KG, Ball S, Cheetham T. Improving the vitamin $\mathrm{D}$ status of vitamin $\mathrm{D}$ deficient adults is associated with improved mitochondrial oxidative function in skeletal muscle. J Clin Endocrinol Metab 2013;98:E509-13.

79. Gupta AK, Sexton RC, Rudney H. Effect of vitamin D3 derivatives on cholesterol synthesis and HMG-CoA reductase activity in cultured cells. J Lipid Res 1989;30:379-86.

80. Riek AE, Oh J, Sprague JE, Timpson A, de las Fuentes L, Bernal-Mizrachi L, et al. Vitamin D suppression of endoplasmic reticulum stress promotes an antiatherogenic monocyte/ macrophage phenotype in type 2 diabetic patients. J Biol Chem 2012;287:38482-94.

81. Cannell JJ, Grant WB, Holick MF. Vitamin D and inflammation. Dermatoendocrinol 2015;6:e983401.

82. Hirschler V, Maccallini G, Sanchez MS, Castaño L, Molinari C. Improvement in high-density lipoprotein cholesterol levels in argentine Indian school children after vitamin D supplementation. Horm Res Paediatr 2013;80:335-42.

83. Hirschler V, Maccallini G, Tamborenea MI, Gonzalez C, Sanchez M, Molinari C, et al. Improvement in lipid profile after vitamin D supplementation in indigenous argentine school children. Cardiovasc Hematol Agents Med Chem 2014;12: 42-9.

84. Islam MZ, Shamim AA, Akhtaruzzaman M, Kärkkäinen M, Lamberg-Allardt C. Effect of vitamin D, calcium and multiple micronutrients supplementation on lipid profile in pre-menopausal Bangladeshi garment factory workers with hypovitaminosis D. J Health Popul Nutr 2014;32:687-95. 